\title{
Lean Implementation in a Manufacturing Industry through Value Stream Mapping
}

\author{
S. V. Kale, R. H. Parikh.
}

\begin{abstract}
Today's market is getting progressively doused step by step, customer ending up progressively self important and hard to persuade that one will offer same value they are searching for, Lean Manufacturing has a route in front of rivalry by envisioning and upgrading the value stream. Value stream mapping (VSM) is a tool in lean execution. It is a strategy to investigate the present condition of procedure and assessing a future condition of the procedure. It takes an item or administration from its start through to end client by lessening waste contrasted with current mapping. In this paper, the first Value stream mapping of the current condition of the procedure is dissected for a situation organization and consequently, the future Value stream map was proposed base on lean standards. In light of the last outcomes, it tends to be the reason that value stream mapping is a helpful apparatus for decreasing waste and non-value included activities
\end{abstract}

Index Terms - Value stream mapping (VSM), Lean Manufacturing (LM).

\section{INTRODUCTION}

During the past two decades, the tools and techniques of lean manufacturing (LM) paradigm are increasingly being implemented in organizations globally. One of the effective strategies for manufacturing organizations is to follow the principles of "lean". (Liu1 \& Yang1, 2017). Initiative of the lean manufacturing is started by Ohno (1978) and Shingo (1989) at Toyoto production system (TPS) in Japan. Main focus behind this system is the efficient and systematic utilization of resources (Ketan \& Yasir, August 2015).

The first time the term lean was described was in the book The Machine that Changed the World (Womack, Jones, \& Roos, 1990).one of the major focus of the LM is waste elimination in every part (inventory, human effort, process). LM includes various tools and exercises that are natural to nearly familiar to almost all Industrial engineer (Braglia, Carmignani, \& F.) (S.S. \& Mohanty, 2007). In numerous such cases, firms have announced a few advantages by applying lean tools; notwithstanding, it is evident that there is a need to comprehend the whole framework so as to increase most extreme advantages of LM (B., Garg, \& C, 2010).

Revised Manuscript Received on July 22, 2019

S. V. Kale, Assistant Professor, Department of Mechanical Engineering, KDKCE, Nagpur, India

Dr. R. H. Parikh, Professor, Department of Mechanical Engineering, KDKCE, Nagpur, India
Value stream mapping (VSM) goes about as one of big business improvement instrument in LM to help with imagining the whole manufacturing process, speaking to both material and data flow. The main objective is to identify a wide range of waste in the value stream and to make vital moves to dispose of them. (Rother \& J., 1999) VSM helps in the development of a "current state map" which demonstrates a visual portrayal of how the organization is presently working; it records process data and data stream which can be utilized to distinguish key squanders, issues and openings. When the present state map has been broken down the future state map would then be created to demonstrate how the organization could work all more adequately (Pavnaskar, J.K., \& A.B., 2003). As indicated by LM framework, VSM is the important apparatus for upgrading of the manufacturing framework and found that there are some key focuses for the creation of the group need to consider for the planning of appropriate information system.

One of the significant difficulties for manufacturing industries is to manufacture assortment items with a base lead time, diminished stock and world-class quality. There is a need to help manufacturing organizations to improve their aggressiveness. (Vinodh \& Viswesh, 2012). Many managers and researchers used VSM as the main tool for identification and waste elimination.

In this paper, the attempt has been made to describe lean implementation through the VSM stepwise.

\section{LITERATURE REVIEW}

VSM is an important tool of LM. VSM can fill in as a decent beginning stage for any venture that needs to be lean. VSM was right off the bat created in Japan in Toyota production system (TPS) in 1980. Jones and Womack (2000) defined VSM as the process of visually mapping the flow of information and material for preparing a future state map with better methods and performance. In any manufacturing industry, the process can be classified in three categories (Hines \& Rich, 1997), these are value-adding activities (VA), non-value adding activities (NVA) and necessary but non-value adding activities (NNVA). NVA are those activities which are not valuable both for the customer and the organization.

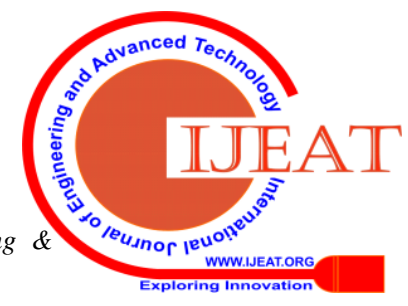




\section{Lean Implementation in a Manufacturing Industry through Value Stream Mapping}

Anything other than the absolute minimum resources of materials, machines, and manpower required to add value to the product is NVA (Hay, 1988). NVA includes unnecessary material handling, excess inventory, and backtracking. NNVA is considered as nonvalue adding by the customer but these are unavoidable in respect of process completion. $\mathrm{It}^{\bullet}$ is difficult to eliminate these types of activities in the short run as it may require major alterations to the existing operational . procedures. (Jasti \& Sharma., 2014).VA activities
are the process to convert the input into output. It is that performance obtained by incurring costs. Customer recognizes these activities and willing to pay for this.

Value stream (VS) is all the actions and tasks include value added and non-value added from initial to a final stage. Mapping of flow of value from an initial stage to customer stage is called VSM. Value stream mapping is done by using symbols. Rother and Shook (1998) have proposed various processes, material, information symbols to draw VSM. The same symbol is used to draw the current state and a future state map of this case study.

\section{OBJECTIVE}

The research objectives have been defined as follows:

- To study and analyze the current manufacturing process

To identify the critical areas of waste

-To identify the opportunities for improvement

-To reduce waste (NVA).

To reduce setting time

To reduce Lead-time of manufacturing

\section{CASE STUDY}

A case study has been carried out in a machining unit of leading auto parts manufacturer located in Nagpur India using VSM. This firm started in 2007 and an ISO certified company. Total of 100 personnel including staff and worker employs in this company. The company works with traditional concepts of manufacturing before lean implementation. The stepwise procedure adopted for this case study as follows:

Fig: PREPARATION OF VSM: PRODUCT SELECTION

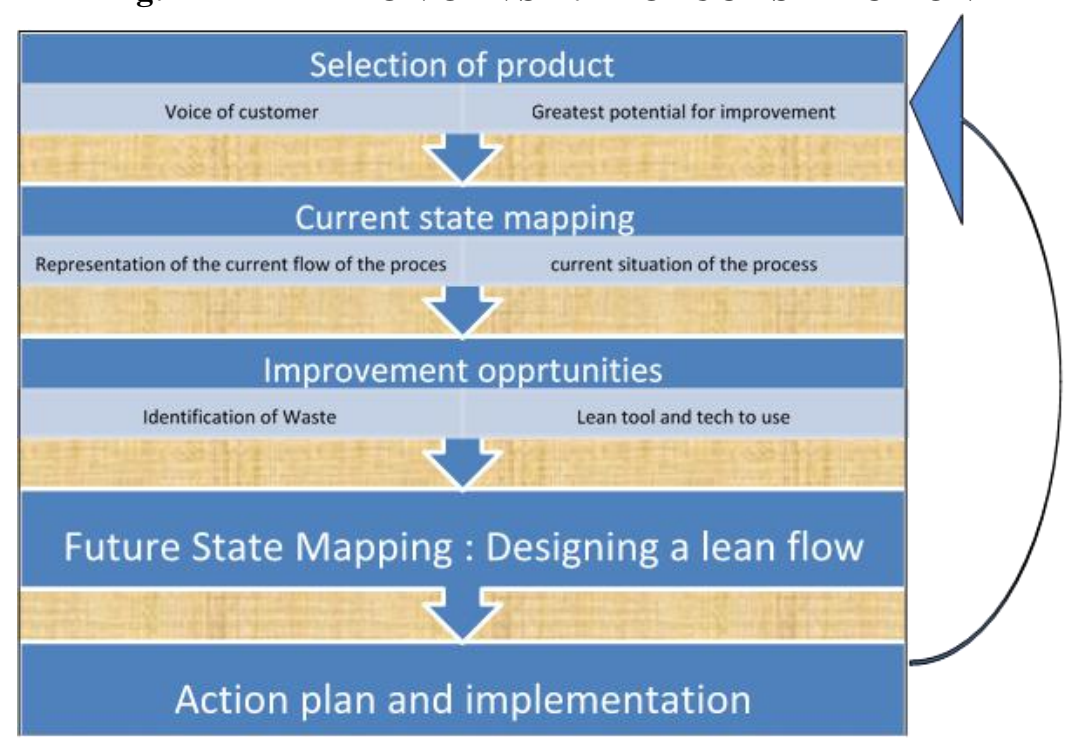

Figure 1 :Steps in VSM

Selecting the product or product family is the first and important step in Current state mapping. This is prepared by selecting the critical product family which has the greatest potential for the improvement. The critical product family is that product segment to make a stream where a max value flow to customer generally 60 to $80 \%$ values should be represented through this stream. It may also decide to go with the highest business volume and stick to the long term objective of the business. If the product variation is more then first conduct the product family analysis this is a simple review of products and process through which they go. Generally, Pareto analysis is used to select the product base on a volume on business or value. This analysis helps the group together the product that share common flow through the process. current value stream map the concentrate on either single product or family of products sharing the common process.

In the case organization different product family mainly categorize under Brass CNC turn components, CNC turn parts castings, Metal CNC turn components, Rough turning parts. Pareto analysis is performed over all this product family and selecting Idler pin machine components for the current state mapping. 


\subsection{PREPARATION OF VSM: SYMBOL USED}

Rother and Shook (1998) have proposed various processes, material, information symbols to draw VSM. The same symbol is used to draw the current state and a future state map of this case study Table 1 shows the symbol for the process, material, information, and general symbol. It is not necessary to use these symbols only if the symbol which describes the process best then use those symbols.

Table 1 : Symbols used in VSM

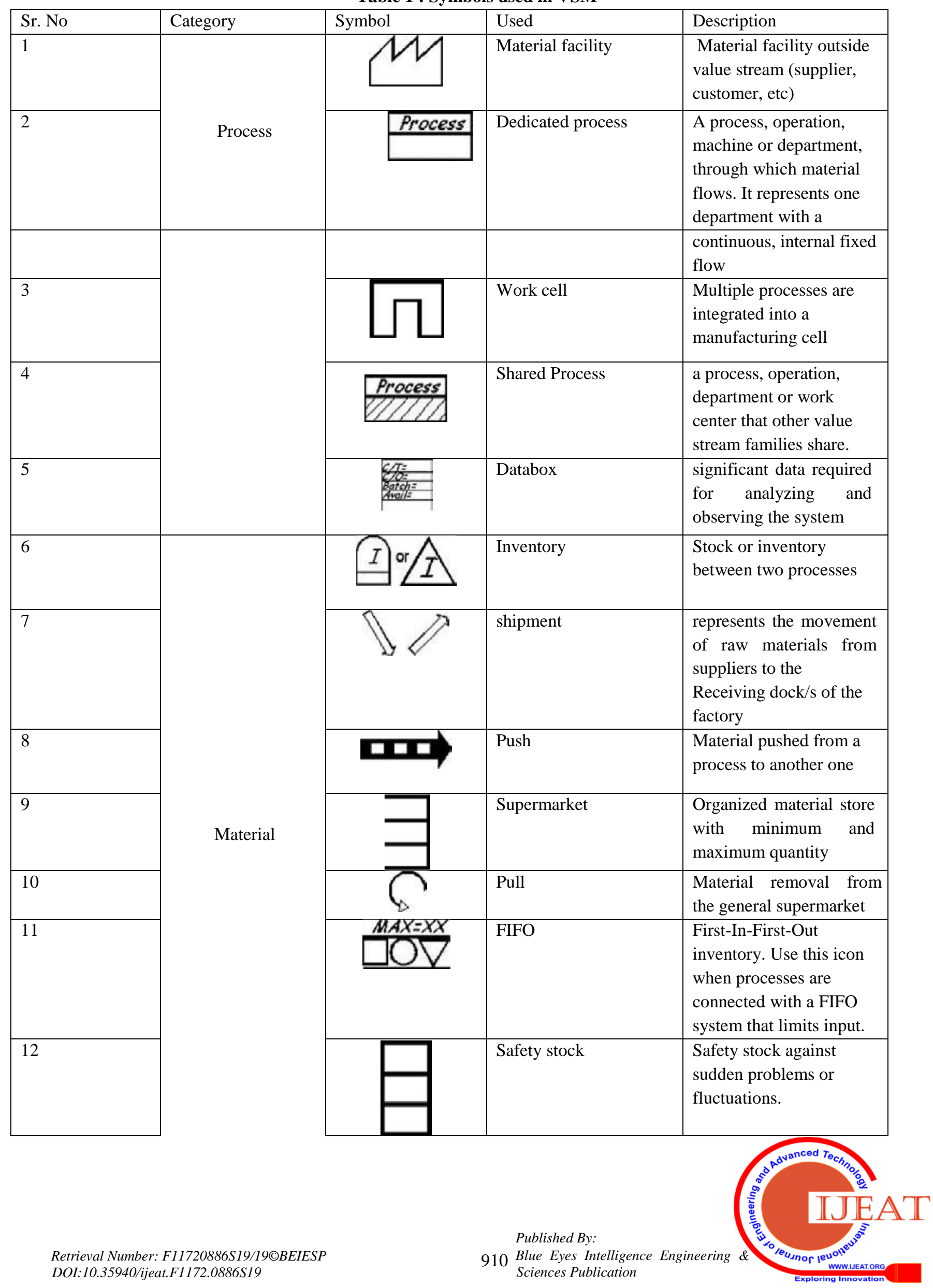


Lean Implementation in a Manufacturing Industry through Value Stream Mapping

\begin{tabular}{|c|c|c|c|c|}
\hline 13 & & & Shipment & $\begin{array}{l}\text { Transport by truck can be } \\
\text { also shown by other } \\
\text { means like boat or plane }\end{array}$ \\
\hline 14 & \multirow{5}{*}{ Information } & \begin{tabular}{|l|} 
Proouction \\
Control
\end{tabular} & Production control & $\begin{array}{l}\text { Production control } \\
\text { department or scheduling } \\
\text {,person or operation. }\end{array}$ \\
\hline 15 & & & Manual Information & $\begin{array}{l}\text { The general flow of } \\
\text { information form reports, } \\
\text { memos or conversation }\end{array}$ \\
\hline 16 & & & Electronic flow & $\begin{array}{l}\text { Information flow through } \\
\text { electronic media like } \\
\text { internet, intranet, LANs, } \\
\text { WANs, fax phone, } \\
\text { mobiles }\end{array}$ \\
\hline 17 & & & Signal Kanban & $\begin{array}{l}\text { Used when a level of } \\
\text { inventory between two } \\
\text { processes triggered } \\
\text { minimum value it is also } \\
\text { known one per batch } \\
\text { Kanban }\end{array}$ \\
\hline \multirow[t]{2}{*}{18} & & & Production kanban & $\begin{array}{l}\text { Production of a } \\
\text { predefined number of } \\
\text { parts.It signals a }\end{array}$ \\
\hline & & & & $\begin{array}{l}\text { supplying process to send } \\
\text { parts to downstream }\end{array}$ \\
\hline 19 & & & MRP/ERP & $\begin{array}{l}\text { Flow scheduling by } \\
\text { MRP/ERP or other } \\
\text { centralized systems }\end{array}$ \\
\hline 20 & & & Verbal information & $\begin{array}{l}\text { Information flow by a } \\
\text { person or verbally }\end{array}$ \\
\hline 21 & & & Sequenced pull & \\
\hline 22 & & & Go see scheduling & $\begin{array}{l}\text { Gathering of information } \\
\text { through visual means like } \\
\text { charts, graphs, diagrams }\end{array}$ \\
\hline 23 & & & Kanban post & $\begin{array}{l}\text { A pull system without } \\
\text { supermarket that gives } \\
\text { instruction to } \\
\text { subassemblies processes } \\
\text { to produce a } \\
\text { predetermined type and } \\
\text { quantity of product }\end{array}$ \\
\hline 24 & & ; W- & Withdrawal Kanban & \\
\hline 25 & & $x O \times 0$ & Load leveling & \\
\hline
\end{tabular}

\subsection{PROCESS BOUNDING}

It is necessary to bound the limits of the map, most of VSM are conducted from supplier through the customer within the firm this is bound the first box placed on VSM to bound the process. It is possible to cover the entire supply chain which include starting from raw material to the end customer. Bound is the envelope to cover under VSM

\subsection{STEPS IN PROCESSES}


Once the processes boundaries are established or envelope for the map is confirmed next step is to decide the steps of a process for the map. Steps are the flow of product from supplier to the customer or vice versa. Process steps are the various operations that are performed on the product. These are points where inventory enter and leave

\subsection{INFORMATION FLOW}

VSM differentiate from other tools by the way information flow into the map. It is important to include how the customer order product, frequency, and method and how it translates back to the supplier. In this also include the requirements of the processes so that the product should be manufactured with a customer perspective.

\subsection{PROCESS DATA COLLECTION}

This is where we need to do a little thinking and some work, gets the team to collect data regarding the performance of each step of the process; typical types of data to collect are;

- Inventory

- Cycle time (time taken to make one product)

- Change over time (from last good piece to next)

- Up-time (on-demand machine utilization)

- Number of operators

- $\quad$ Shifts worked

- Net available working time

- Scrap rate

- $\quad$ Pack size/pallet sizes

- Batch

\subsection{PREPARATION OF VSM: CURRENT STATE MAPPING}

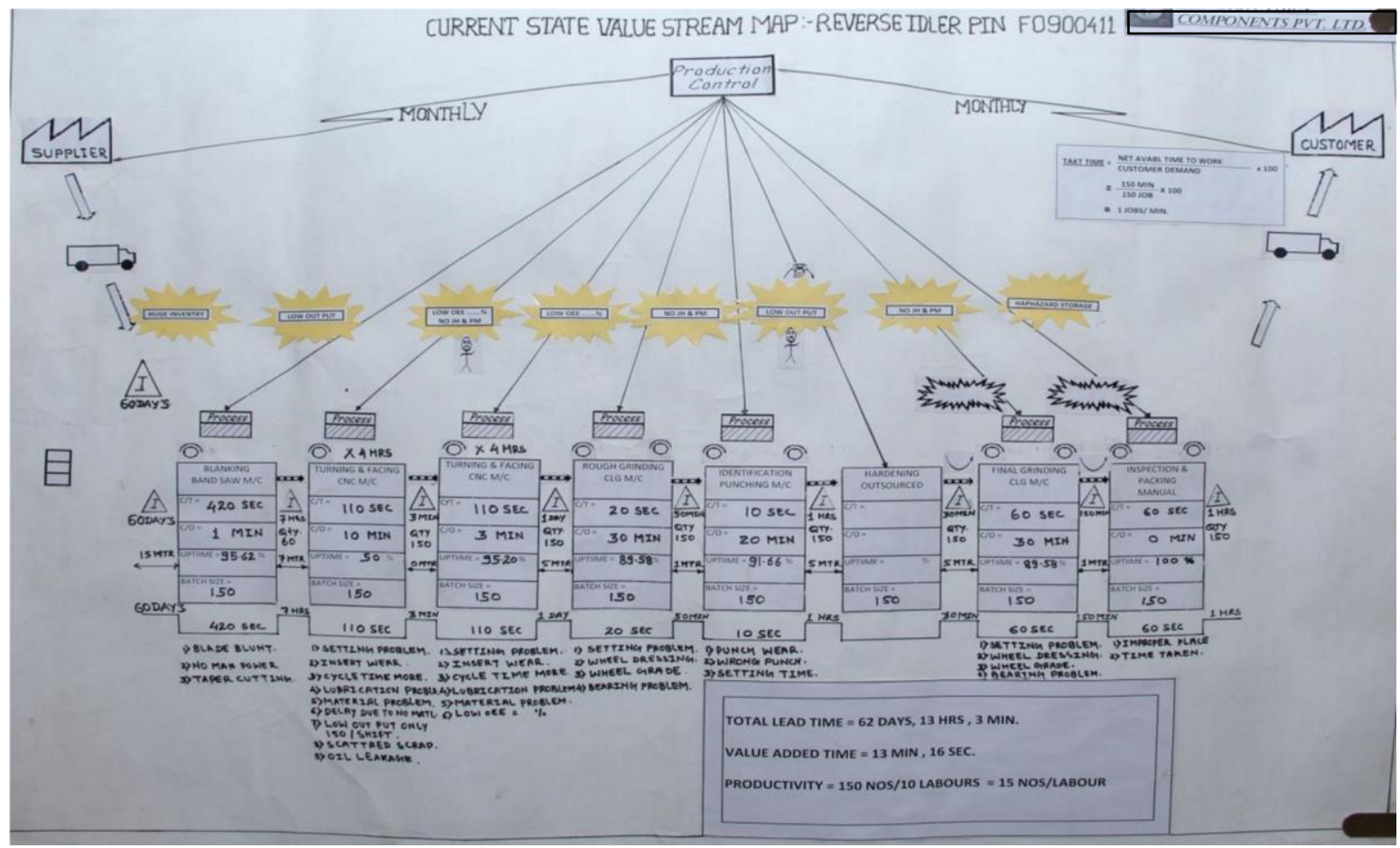

Figure 2: Current State mapping

Current state map (CSM) shows the current activities involved in the idler pin manufacturing in the case organization from the raw material acquisition to the delivery to the customer. It shows the processes involved in the production of idler pin and their cycle time right up to delivery to the customer. The data for the CSM was collected from the stores, operators on Machines like the band saw, CNC turning, rough grinding machine, punching machine and hardening as well final grinding machine. The average time for the manufacturing which usually called lead or task time is calculated as Takt time $=$ Available time / Customer demand

Takt time $=480 / 480=1 \mathrm{~min}$

From the above calculation, it is to be found that $1 \mathrm{~min}$ is required at which band saw machine has to cut the blank to satisfy the customer demand. 
Lean Implementation in a Manufacturing Industry through Value Stream Mapping

Table 2: Comparision VSM of current and future state

\begin{tabular}{|c|c|c|c|}
\hline Sr, No. & CSM & VSM & Issue resolved \\
\hline 1 & $\begin{array}{c}\text { Congestion of material on } \\
\text { Band saw machine }\end{array}$ & $\begin{array}{c}\text { Kaizen Done } \\
\text { reduced }\end{array}$ \\
\hline 2 & $\begin{array}{c}\text { Facing and turning CNC } \\
\text { machine programming } \\
\text { time long }\end{array}$ & $\begin{array}{c}\text { Process improve by } \\
\text { analysis and tooling }\end{array}$ & Reduced lead time \\
\hline 3 & $\begin{array}{c}\text { Inspection taking a long } \\
\text { time }\end{array}$ & No. of operator increases & Inspection time reduced \\
\hline
\end{tabular}

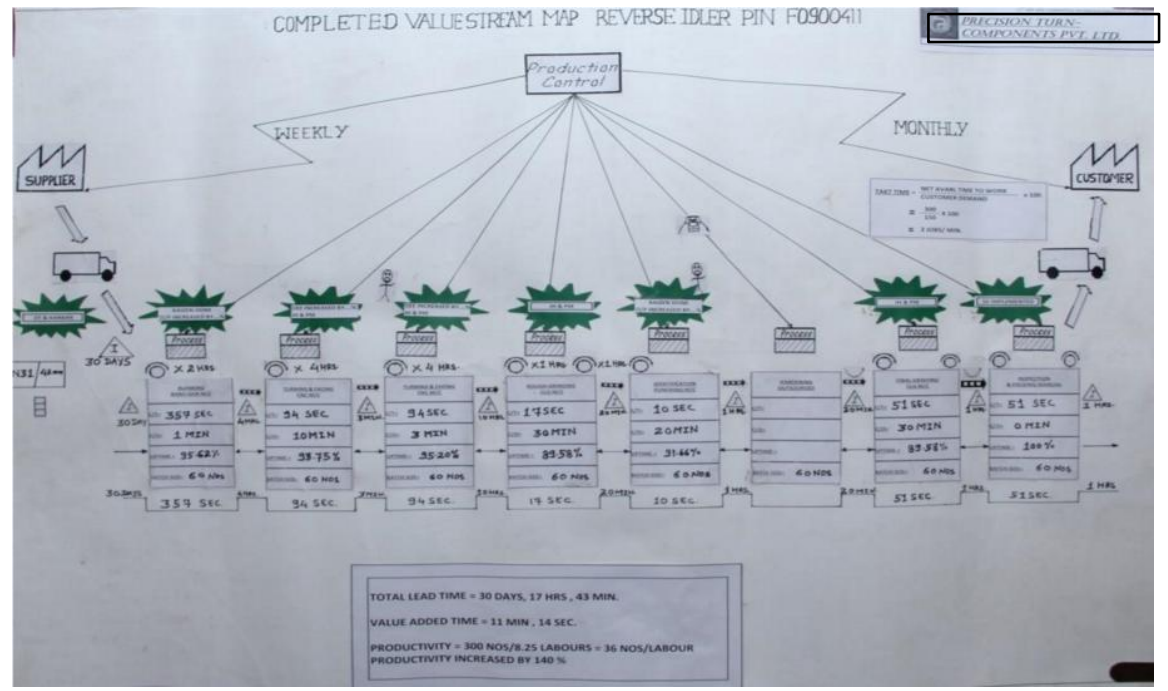

Figure 3 : Future state mapping

The customer informed the demand telephonically to the production planning department (PPC).Currently, inventory in the store is for 3 days.

Material moves from raw material store to the finished product store through various process

Major concerns were the following

i) Receiving store has very high inventory

ii) Band saw machine uses the cutting blade for raw material cutting required frequent sharpening thus cutting a required lot of time

iii) After cutting raw material accumulation of material as a lot of components spend a lot of time on this station

Inspection is done by only one inspector required a lot of time on that station.

Future state map which was drawn by assuming that all issues in the critical area was resolved. But in practice,ball issues can not be resolved completely. Comparison between CSM and VSM is shown in the table below It canbe seen from the VSM and CSM that lead time of the process reduced by $141 \mathrm{~min}$ and value-added time by $11 \mathrm{~min}$. The lead time of the product is reduced by $140 \%$

\section{RESULTS AND DISCUSSION}

As mentioned in the diagram, current VSM indicated a high cycle of process. total lead time for current sate value stream map and future value stream map is differed and improved with 32 days and 4 hrs. From Future State Map it is observed that the inventory time is reduced from 30 days to 25 days and the total lead time is reduced from 30 days 1 hour 33 minutes to 28 days 1 hour 33 minutes

\section{REFERENCES}

1. B., S., Garg, S., \& C, S. S. (2010). Lean implementation and its benefits to production industry. International Journal of Lean Six Sigma, 157-168.

2. Braglia, M., Carmignani, \& F., G. a. (n.d.). A new value stream mapping approach for complex production systems. International Journal of Production Research, 3929-3952.

3. Hay, E. J. (1988). Just-In-Time Breakthrough: Implementing the New Manufacturing Basics. John Wiley \& Sons Inc.

4. Hines, P., \& Rich, N. (1997). The seven value stream mapping tools International journal of operations \& production management, 46-64.

5. Jasti, N. V., \& Sharma., A. (2014). Lean manufacturing implementation using value stream mapping as a tool A case study from auto components industry. International Journal of Lean Six Sigma , 89116.

6. Ketan, H. S., \& Yasir, F. M. (August 2015). Reducing of Manufacturing Lead Time by Implementation of Lean Manufacturing Principles. Journal of Engineering .

7. Liu1, Q., \& Yang1, H. (2017). Lean Implementation Through Value Stream Mapping: A Case Study of A Footwear Manufacturer. IEEE.

8. Pavnaskar, S., J.K., G., \& A.B., J. (2003). Classification scheme for lean manufacturing tools. International Journal of Production Research, 3075-3090.

9. Rother, M., \& J., S. (1999). Learning to See: Value Stream Mapping to Create Value and Eliminate Muda. Lean Enterprise Institute, Cambridge, MA.

10.S.S., M., \& Mohanty, S. (2007). Lean manufacturing in continuous process industry:an empirical study. Journal of Scientific and Industrial Research , 19-27.

11. Vinodh, S., \& Viswesh, S. S. (2012). AHP-based lean concept selection in a manufacturing organization. Journal of Manufacturing Technology Management, 124-136.

12. Womack, J., Jones, D., \& Roos, D. (1990). Machine that changed the world. 